\title{
CAMA
}

Centre for Applied Macroeconomic Analysis

\section{Consumer Loss in Czech Photovoltaic Power Plants}

\section{CAMA Working Paper 50/2013 August 2013}

\section{Jan Prusa}

Institute of Economic Studies, Faculty of Social Sciences, Charles University in Prague, Czech Republic

\section{Andrea Klimesova}

Institute of Economic Studies, Faculty of Social Sciences, Charles University in Prague, Czech Republic

\section{Karel Janda}

Institute of Economic Studies, Faculty of Social Sciences, Charles University in Prague Department of Banking and Insurance, Faculty of Finance and Accounting, University of Economics, Prague, Czech Republic, and

Centre for Applied Macroeconomic Analysis (CAMA), ANU 


\section{Abstract}

This article provides a financial survey of a small sample of Czech photovoltaic (PV) plants. To evaluate the extent of market losses, we calculate the shadow market price of solar electricity. From the profit and loss accounts of the PV plants and the shadow market price we estimate the total economic loss generated by PV electricity sector in the Czech Republic. The presented microeconomic approach has two main advantages: Firstly, we work with real observed data, which offsets the drawback of a limited sample. Secondly, the profit accounting calculation enables sensitivity analysis with respect to key variables of the plants. We show that money invested in PV plants would generate an annual loss of 8\%. Given the estimated solar assets of CZK 165.6 billion (EUR 6.6 billion) as of December 2011, this translates in at least CZK 12.6 billion lost in the Czech solar sector in 2012. About $43 \%$ of this loss is due to high technology costs and corresponds to pure dead weight loss, while the remaining $57 \%$ constitute the redistributive profit component of subsidies. Finally, we calculate that unless electricity prices increase or technology costs decrease approximately sevenfold, PV plants will remain loss making.

\section{Keywords}

energy subsidies; photovoltaic; renewables

\section{JEL Classification}

JEL: Q42; H23; M21

\section{Address for correspondence:}

(E) cama.admin@anu.edu.au

The Centre for Applied Macroeconomic Analysis in the Crawford School of Public Policy has been established to build strong links between professional macroeconomists. It provides a forum for quality macroeconomic research and discussion of policy issues between academia, government and the private sector.

The Crawford School of Public Policy is the Australian National University's public policy school, serving and influencing Australia, Asia and the Pacific through advanced policy research, graduate and executive education, and policy impact. 


\title{
Consumer Loss in Czech Photovoltaic Power Plants
}

\author{
Jan Průša ${ }^{a}$, Andrea Klimešováa ${ }^{a}$, Karel Janda ${ }^{a, b, c}$ \\ ${ }^{a}$ Institute of Economic Studies, Faculty of Social Sciences, Charles University in Prague. Opletalova \\ 26, 11000 Prague, Czech Republic. \\ ${ }^{b}$ Department of Banking and Insurance, Faculty of Finance and Accounting, University of Economics \\ (VSE). Naměstí Winstona Churchilla 4, 13067 Prague, Czech Republic. \\ ${ }^{c}$ Centre for Applied Macroeconomic Analysis (CAMA), Australian National University, J.G. Crawford \\ Building, number 132, Canberra ACT 0200, Australia.
}

\begin{abstract}
This article provides a financial survey of a small sample of Czech photovoltaic (PV) plants. To evaluate the extent of market losses, we calculate the shadow market price of solar electricity. From the profit and loss accounts of the PV plants and the shadow market price we estimate the total economic loss generated by PV electricity sector in the Czech Republic. The presented microeconomic approach has two main advantages: Firstly, we work with real observed data, which offsets the drawback of a limited sample. Secondly, the profit accounting calculation enables sensitivity analysis with respect to key variables of the plants. We show that money invested in PV plants would generate an annual loss of 8\%. Given the estimated solar assets of CZK 165.6 billion (EUR 6.6 billion) as of December 2011, this translates in at least CZK 12.6 billion lost in the Czech solar sector in 2012. About $43 \%$ of this loss is due to high technology costs and corresponds to pure dead weight loss, while the remaining $57 \%$ constitute the redistributive profit component of subsidies. Finally, we calculate that unless electricity prices increase or technology costs decrease approximately sevenfold, PV plants will remain loss making.
\end{abstract}

Keywords: energy subsidies; photovoltaic; renewables

JEL: Q42; H23; M21

Email addresses: jan.prusa@ies-prague.org (Jan Průša), andrea-klimesova@centrum.cz (Andrea Klimešová), karel-janda@seznam.cz (Karel Janda) 


\section{Introduction}

Concerns about anthropogenic global warming (also referred to as climate change) and carbon emissions led goverments around the world to adopt various energy policy measures with significant financial impact on public budgets. The most widespread measures include subsidies of renewable sources of energy, especially photovoltaic (PV) electricity generation.

While some authors (Pearce, 2002) emphasize the positive contribution of photovoltaic energy to limiting carbon emissions, several affairs of the PV sector recently caught negative attention in the media: (1) Generation of subsidized green electricity at night using diesel aggregates in Spain. This particular case received extensive international coverage (Bloomberg, 2010). (2) Bankruptcies of several large PV companies, including PV panel producers Evergreen Solar and Solyndra. Solyndra even received $\$ 535$ million of US federal government guaranteed debt to finance its expansion. The company reported assets of $\$ 859$ million and debt of $\$ 749$ million (Bloomberg, 2011d) When Evergreen Solar filed for bankruptcy, it owed its creditors $\$ 485.6$ million while listing assets of \$424.5 million (Bloomberg, 2011a). German PV panel producer Solon SE filed for insolvency in December 2011, with debt of EUR 570m and assets of EUR $466 \mathrm{~m}$ as of September 2011 (Bloomberg, 2011b). (3) Rapidly increasing electricity price for Czech customers due to PV energy subsidies. The surcharge for renewable sources paid by consumers amounted to $166.34 \mathrm{CZK} / \mathrm{MWh}$ or $6.7 \mathrm{EUR} / \mathrm{MWh}$ in 2010 (ERÚ, 2009) and jumped to $419.22 \mathrm{CZK} / \mathrm{MWh}$ or $16.8 \mathrm{EUR} / \mathrm{MWh}$ in 2012, an increase of $152 \%$ (ERÚ, 2011). (Note that throughout this text we use the exchange rate of 25 CZK/EUR.)

This study concentrates on the last case. We provide a survey of PV plants in the Czech Republic, where we focus on large greenfield projects. We analyze their profitability and decompose their cost structure. We calculate alternative revenue scenario based on market prices, which allows us to calculate the real revenue gap needed to be covered by subsidies. This follows the approach of Borenstein (2008), who employs this procedure to determine the market value and cost of PV electricity in the U.S.

Dusonchet and Telaretti (2010a, table 11) show that Czech Republic, along with Slovakia and Bulgaria, are among the three Central and Eastern EU member states with the most generous PV subsidy programmes. However most western EU countries have still more profitable PV subsidies, as documented in Dusonchet and Telaretti (2010b, table 20). Súri et al. (2007, p. 1298) name Czech Republic along with Germany as an example where "policy has stimulated PV growth even in regions with moderate solar 
energy resource". Thus Czech Republic is a very clear example of a Central and Eastern European country which joined rich western EU countries in their generous PV support.

This calls for a detailed analysis of impacts of the supportive PV policy. Hitherto evaluations of Czech PV subsidies (including Dusonchet and Telaretti, c.f.) are typically based on a top-down approach calculating merely with the value of feed in tariffs (hereninafter FIT, defined in the next section), without taking into account the detailed cost structure of these plants. One of the exceptions are Lewandowski et al. (2006, table 9) who present detailed cost projections for production of electricity from biomass in the Czech Republic. Our approach has the benefit that we look at the single plant level to build a comprehensive view of their microeconomics and how efficiently these plants turn the subsidies into profits. Above all we look at depreciation schedules and financing costs. When compared with estimated market value of PV generated electricity, as a result we provide a thorough estimation of the dead weight loss which was caused by Czech PV subsidies.

There is a growing amount of literature devoted to economic analysis of PV plants. The U.S. market was analyzed in great detail e.g. by Wiser et al. (2009) and Borenstein (2007). The former paper tracks the cost of PV plants in terms of assets that were built, while the latter models the move away from cross-subsidization by means of time-of-use rates. The Czech case was most recently described by Smrčka (2011), who argues against the efficiency of PV subsidies in terms of theoretical political economy. To the best of our knowledge our microeconomic survey is completely novel in the field.

The rest of the paper is organized as follows: In section 2 we introduce general theoretical considerations on PV subsidies along with the legislation background. In section 3 we present the core microeconomic survey of selected PV plants. Figures from this survey enter our calculation of dead weight loss in section 4. Section 6 concludes.

\section{Theoretical Considerations}

\subsection{Understanding PV Costs}

It goes without saying that without subsidies PV plants would generate losses, otherwise subsidies would not be needed in the first place. These losses stem above all from significant requirements for capital investment into plant equipment. Not only are solar panels produced by expensive technology. The panels also use costly materials and are relatively fragile, which shortens their expected lifetime.

The situation was made worse by the subsidies themselves, because the governments in fact generated a perfect PV bubble. Polysilicon, the major component of solar panels, illustrates the case: 
Polysilicon has been used as a semiconductor in computer microchips for decades. Supplies only became scarce from 2004, when European nations began introducing subsidies for clean energy. The price soared to $\$ 475$ [per kilo] in March 2008 from about $\$ 30$ in 2003. New capacity began to come on stream in 2008. (Bloomberg, 2011c)

As of 2011 year-end the price has fallen back to $\$ 33$ due to massive jump in capacity and fall in demand. At this price however, some producers are making big losses and will have to close down. On this example we see the size of the shock that is imposed on the economy because of one simple policy.

In the Czech Republic we will evaluate the size of this shock in more detail. We will analyze the case of feed-in tariffs, which is a common way to subsidize electricity from PV plants. An excellent overview of other options to support PV plants is provided by Timilsina et al. (2011, sec. 5).

FIT are defined as a scheme in which producers of PV electricity are paid for each unit certain guaranteed fixed price above market price. Such subsidies of course do not lower costs of PV electricity at the outset, although it can be argued that by encouraging installations they help the technology to reach economies of scale and consequent cost reductions (Sandén, 2005). For example, Barbose et al. (2012, figure 7) document the decreasing unit price of new installations in the United States for the period 1998-2011.

As long as the cost of technology remains high however, customers are charged more for electricity than their original willingness to pay. In the Czech case it was the regional electricity distribution companies who were required by law in 2010-2011 to pay artificially high price to PV producers. Distribution companies were then allowed to pass this additional cost onto end consumers. This PV surcharge was spread over all units of electricity sold, so that end customers ended up paying higher average electricity price.

The subsidized price can be decomposed into three parts. The first part of the price $p_{01}$ covers the average cost of electricity in the grid produced by standard plants. Price $p_{01}$ approximately corresponds to the market price at which electricity is traded on the commodity exchange. To the extent that average cost of PV plants is higher than average cost of the remaining sources, there is dead weight loss in the economy induced by the subsidies. The difference between PV average cost and $p_{01}$ is the second subsidized price component $p_{02}$, which we call the pure DWL component. Finally the third component $p_{03}$ is the amount above PV average cost which constitutes profits of PV plant owners. As we shall see below a significant part of the subsidies goes to this profit component.

This decomposition is shown in figure 1. While in reality the electricity market is 
Figure 1: The Impact of PV Subsidies on the Electricity Market
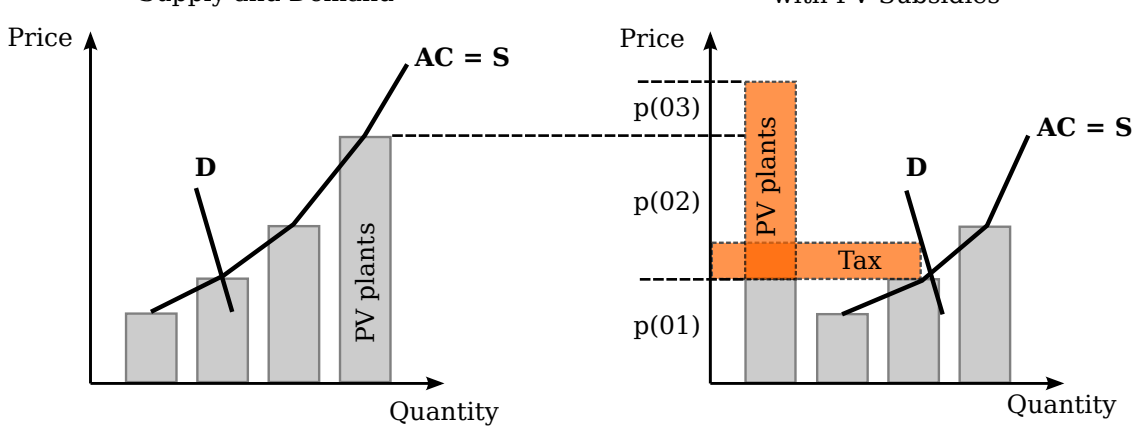

Note: Proportions in this figure do not correspond to real values.

affected by many factors such as availability of the specific sources, the figure schematically captures long-term average costs and the way how subsidies in the form of FIT shift PV power from not economically feasible to a utilized source. The shaded rectangles indicate various sources of electricity, typically these would be nuclear, lignite/coal and natural gas plants, as well as variable renewable resources such as hydropower. Note that the costs depicted here include the interest accrued to creditors and shereholders. PV plants are initially at the right end because their cost is above market cost. The figure on the right shows how the situation changes after PV subsidies are introduced. The supply curve is distorted, as suddenly PV plants are shifted to the left. A green tax is introduced which is paid by all consumers, driving the price above the natural market price. The proceeds are distributed to PV plants to cover their excessive costs $\left(p_{02}\right)$ and any additional profits made by PV plant operators $\left(p_{03}\right)$. Hence the two dotted (orange) rectangles have an equal area.

In reality the subsidies can be financed from other sources than just a tax-driven price increase. In the Czech Republic, for example, the sum of subsidies granted to PV operators was covered by three sources: (1) the green tax on electricity price, (2) the proceeds from the sale of $\mathrm{CO} 2$ permits to companies, and (3) a special tax on profit of PV plants operators.

The empirical counterpart to the left chart in figure 1 is depicted in figure 2. Figure 2 shows estimated unit electricity costs according to the Boston Consulting Group, along with the approximate breakdown of the total price into the main components: capital expenditures required (fixed costs), operating expenditures excl. fuel (variable costs), 
Figure 2: Estimated unit electricity costs in EUR/MWh according to BCG The Boston Consulting Group (2011).

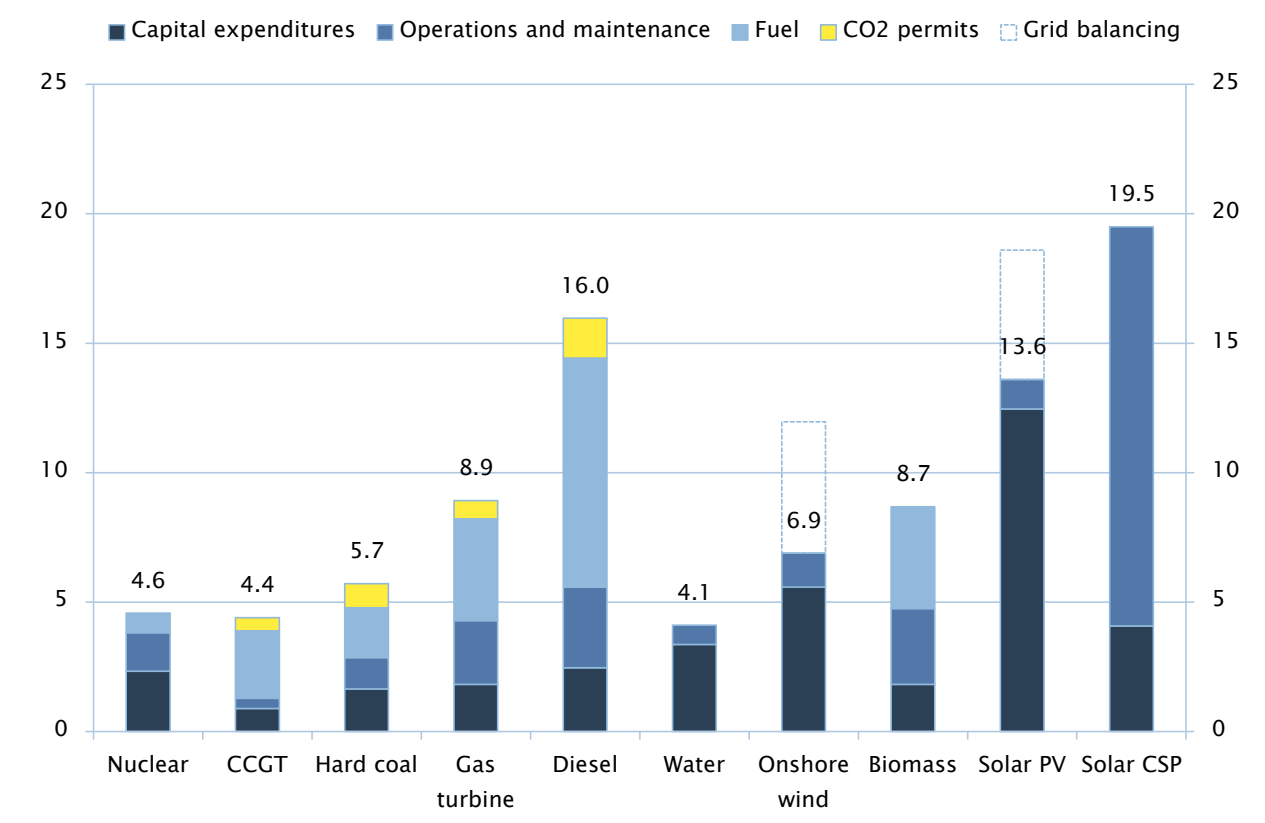

Note: $\mathrm{CCGT}=$ Combined cycle gas turbine. $\mathrm{CSP}=$ Concentrated solar power. Assumptions: $\mathrm{CO} 2$ price $20 \mathrm{EUR} / \mathrm{t}$, gas price $25 \mathrm{EUR} / \mathrm{MWh}$, oil price $80 \mathrm{USD} / \mathrm{bbl}$.

fuel costs and $\mathrm{CO} 2$ emission permits.

Additionally, for onshore wind energy and for PV plants the figure also shows estimates of costs of grid balancing which are not paid by the producer but by the grid operator. The balancing costs arise because electricity generation by these sources depends on weather conditions that cannot be influenced and that are independent of demand. This so called intermittency problem was analyzed in great detail by e.g. Gowrisankaran et al. (2011). Currently grid operators have to devote significant resources to balancing when these sources suddenly start or stop producing electricity. Even though the costs indicated in figure 2 are rough estimates and would in practice vary across countries, we include the figure to provide a reality check for figure 1. 


\subsection{The Redistributive Nature of Subsidies}

It is crucial to distinguish between the above listed components of subsidized price of PV electricity. The pure DWL component is a net loss to the economy, because it captures the extent of inefficient electricity production. $p_{02}$ is equivalent to an artificial cost which would not exist were it not for the subsidies. This cost appears because money is invested in PV production capacity that is more expensive than other feasible sources. The component represents a sum that could have been saved if the cheaper sources had been selected, and it could have been spent on other goods (e.g. cars), thus increasing consumer utility. As this wealth cost trickles through all segments of the economy in a multiplicating way, we certainly know that this cost is carried by all citizens, even those who otherwise participate in financial benefits from PV subsidies. Other than that we cannot say much about exact proportions in which different groups of consumers will bear this cost.

The profit component $p_{03}$ is different: It is in fact a pure redistributive tax. Just as any other sales tax, $p_{03}$ increases price of the good (electricity) and the proceeds are redistributed, in this case to PV plant owners. Taxes induce inefficiencies of their own, which we leave aside at this point. However we can determine the effect of this quasi-tax on consumers. The demand for electricity is highly inelastic, and electricity bills take a higher share of living cost for the poor than for the rich. Moreover this profit goes directly to capitalist investors in the PV sector. From these three points we therefore derive that the profit component $p_{03}$ is tax regressive.

It is worth noting that a carbon tax has the same effect. Due to low elasticity of demand, producers of electricity can pass this additional cost on consumers, and the tax is again born by all citizens. This is why we conclude that the effect of a carbon tax is regressive as well.

\subsection{Czech Legislation}

The subsidies of PV electricity in the Czech Republic were introduced due to the legally binding Directive 2009/28/EC (European Council, 2009). Following this directive the Czech Ministry of Industry (2010) prepared the National Renewable Energy Action Plan (NREAP), which outlines targeted shares of each energy source on total consumption until 2020.

Even though the NREAP proposes to increase the share of renewables on total energy consumption from $8.3 \%$ in 2010 to $13.5 \%$ in 2020 , it does not even touch the topic of costs of this plan. The evaluation of costs and benefits of renewable subsidies is not a 
mandatory part of the NREAP, therefore this part was left empty in the Czech NREAP, see Czech Ministry of Industry (2010, p. 75).

Specifically the NREAP defines the target for PV electricity to be 1,695 MW of installed capacity as of 2020, gradually increasing from 1,650 MW that were to be reached in 2010 (p. 80). However this plan was exceeded already in 2010 by $170 \mathrm{MW}(+10 \%)$ and in 2011 by $311 \mathrm{MW}(+19 \%$, see below table 4$)$. This suggests that the subsidies for PV plants, and accordingly the costs for Czech consumers, were set quite high. We now turn to a rigorous examination of these costs.

\section{Czech PV Plants}

\subsection{Summary of Surveyed Plants}

This part surveys the segment of photovoltaic power plants in the Czech Republic. We depart from microeconomic analysis of individual companies operating the largest Czech PV plants. For the purpose of our calculations we needed to collect both production and financial data for the surveyed plants. This limited the relevant sample.

We collected production data from the regular annual surveys of electricity market published by the Czech Energy Regulatory Office (ERÚ) for 2010 (Lukáš, 2011) and for 2011 (ERÚ, 2012). As for the 2010 sample, we selected those plants which started production in 2009 , so that they already went through a full year of operation in 2010 . As for the 2011 sample, all plants mentioned in the ERÚ report had been put into operation in earlier years.

We then matched these plants with their publicly available financial reports from the Czech Business Register (Czech Ministry of Justice, 2013). While for the 2011 sample we could find all relevant reports, for the 2010 sample some of the plants only published delayed reports from 2009, as indicated in Financial Report column in table 1.

Table 1 shows production of sample plants compared to their capacity. Capacity usage in the last column is computed as the ratio of production to capacity in $\mathrm{MWh} / \mathrm{MW}_{e}$ (i.e. in hours). Dividing this by the total number of hours in the year $(8,760)$ we get the percentage usage of the plants. Average usage of the plants was 734 hours (8.38\%) for 2010 and 1,099 hours (12.54\%) for 2011. The 2010 result is in line with those of Šúri et al. (2007, p. 1298) who calculate theoretical usage of plants based on insolation taken from the Solar radiation database. They show on the map that Czech Republic lies mostly in the area with potential usage of 700-800 hours. The 2011 result is higher, perhaps due to the fact that these plants are significantly larger and thus investors selected their locations more carefully. 
Table 1: Summary of sample PV plants.

\begin{tabular}{|c|c|c|c|c|c|c|c|c|}
\hline & $\begin{array}{l}\text { Legal } \\
\text { form }\end{array}$ & $\begin{array}{r}\text { Financial } \\
\text { report } \\
Y e a r\end{array}$ & $\begin{array}{r}\text { Total } \\
\text { assets } \\
C Z K \text { mil. }\end{array}$ & $\begin{array}{r}\text { Fixed } \\
\text { assets } \\
C Z K \text { mil. }\end{array}$ & $\begin{array}{r}\text { Production } \\
\text { capacity } \\
M W_{e}\end{array}$ & $\begin{array}{r}\text { Annual } \\
\text { production } \\
M W h \text { net }\end{array}$ & $\begin{array}{r}\text { Capacity } \\
M W h / M W_{e}\end{array}$ & usage \\
\hline \multicolumn{9}{|l|}{2010 sample } \\
\hline $\begin{array}{l}\text { REN POWER } \\
\text { II }\end{array}$ & s.r.o. & 2010 & 521.1 & 464.3 & 7.3 & 5,130 & 706 & $8.06 \%$ \\
\hline Solar Stribro & s.r.o. & 2010 & $1,762.1$ & $1,588.3$ & 13.6 & 13,056 & 959 & $10.95 \%$ \\
\hline FVE Czech & a.s. & 2010 & 593.6 & 553.2 & 6.1 & 6,372 & 1,047 & $11.95 \%$ \\
\hline BS Park I & s.r.o. & 2009 & 196.5 & 128.1 & 8.1 & 2,637 & 325 & $3.71 \%$ \\
\hline Papeno & s.r.o. & 2009 & 603.6 & 519.4 & 8.4 & 5,222 & 618 & $7.06 \%$ \\
\hline ČEZ OZ & s.r.o. & 2010 & $4,669.7$ & $4,316.3$ & 21.3 & 15,911 & 747 & $8.53 \%$ \\
\hline $\begin{array}{l}\text { All plants in } \\
2010\end{array}$ & & & & & 64.8 & 48,328 & 734 & $8.38 \%$ \\
\hline \multicolumn{9}{|l|}{2011 sample } \\
\hline 3L Invest & a.s. & 2011 & $4,086.3$ & $3,887.8$ & 38.3 & 39,962 & 1,043 & $11.91 \%$ \\
\hline $\begin{array}{l}\text { FVE } \quad \text { Czech } \\
\text { Novum }\end{array}$ & s.r.o. & 2011 & $2,980.7$ & $2,613.6$ & 35.1 & 40,383 & 1,151 & $13.13 \%$ \\
\hline Gentley & a.s. & 2011 & $2,582.3$ & $2,444.8$ & 29.9 & 32,533 & 1,088 & $12.42 \%$ \\
\hline $\begin{array}{l}\text { AREA- } \\
\text { GROUP } \\
\text { CL }\end{array}$ & a.s. & 2011 & $1,881.1$ & $1,747.4$ & 17.5 & 17,629 & 1,007 & $11.50 \%$ \\
\hline DOMICA FPI & s.r.o. & 2011 & $1,330.7$ & $1,308.0$ & 16.0 & 18,365 & 1,148 & $13.10 \%$ \\
\hline ŽV - SUN & s.r.o. & 2011 & $1,560.8$ & $1,111.8$ & 13.0 & 13,051 & 1,004 & $11.46 \%$ \\
\hline Divalia & a.s. & 2011 & 729.6 & 613.2 & 10.2 & 12,185 & 1,195 & $13.64 \%$ \\
\hline $\begin{array}{l}\text { All plants in } \\
2011\end{array}$ & & & & & 121.7 & 134,146 & 1,099 & $12.54 \%$ \\
\hline
\end{tabular}

Note: s.r.o. = limited liability company, a.s. = joint stock company.

Source: Czech Business Register (Czech Ministry of Justice, 2013), Lukáš (2011), ERÚ (2012), own calculations.

\subsection{Balance Sheet Indicators}

From available financials we calculated the most important balance sheet indicators. We exclude ČEZ Obnovitelné zdroje (ČEZ OZ) in this evaluation because their portfolio includes water and wind power plants.

The equity to assets ratio shows sources of asset financing for PV plants, which can be either equity or liabilities. In our sample this ratio averages mere $8.8 \%$ for 2010 and $16.5 \%$ for 2011 , the remaining share of assets $(91.2 \%$ and $83.5 \%$ respectively) being funded by liabilities, which in turn are mostly represented by bank debt or shareholder loans. For the 2010 sample this means that if the company has 10 million of assets, less than one million was financed by shareholders' equity and the rest was financed from 
loans. PV plants are typically highly leveraged projects where banks are the dominant stakeholders.

Table 2: Balance Sheet and Income Statement Indicators for Sample PV Plants.

\begin{tabular}{|c|c|c|c|c|c|c|c|}
\hline & $\begin{array}{r}\text { Equity } \\
\text { Assets } \\
\%\end{array}$ & $\begin{array}{r}\frac{\mathbf{P P E}}{\mathbf{M} \mathbf{W}_{e}} \\
C Z K \text { mil. }\end{array}$ & $\begin{array}{c}\frac{\text { Liabilities }}{\mathrm{MW} e} \\
C Z K \text { mil. } \\
C\end{array}$ & \multicolumn{4}{|c|}{$C Z K / M W h$} \\
\hline \multicolumn{8}{|l|}{2010 sample } \\
\hline REN POWER II & $3.52 \%$ & 63.9 & 68.9 & 15,444 & 15,079 & 5,497 & 4,068 \\
\hline Solar Stribro & $23.28 \%$ & 116.7 & 99.3 & 13,125 & 10,403 & 4,645 & 6,033 \\
\hline FVE Czech & $8.35 \%$ & 90.9 & 89.4 & 13,057 & 11,962 & 3,291 & 3,838 \\
\hline BS Park I & $-0.20 \%$ & 15.8 & 24.3 & & & & \\
\hline Papeno & $9.22 \%$ & 54.9 & 64.9 & & & & \\
\hline Average in 2010 & $8.83 \%$ & 68.0 & 69.3 & 13,875 & 12,481 & 4,478 & 4,646 \\
\hline \multicolumn{8}{|l|}{2011 sample } \\
\hline 3L Invest & $17.38 \%$ & 101.5 & 88.2 & 12,128 & 8,594 & 2,003 & 2,402 \\
\hline FVE Czech Novum & $8.83 \%$ & 74.5 & 76.8 & 12,421 & 8,237 & 2,391 & 3,486 \\
\hline Gentley & $17.42 \%$ & 81.8 & 71.3 & 11,977 & 8,153 & 3,872 & 5,064 \\
\hline AREA-GROUP CL & $16.81 \%$ & 99.8 & 89.4 & 11,964 & 8,057 & 2,005 & 2,672 \\
\hline DOMICA FPI & $21.39 \%$ & 81.8 & 65.4 & 12,132 & 8,467 & 3,666 & 3,686 \\
\hline ŽV - SUN & $26.60 \%$ & 85.5 & 86.8 & 16,014 & 7,707 & 4,092 & 3,295 \\
\hline Divalia & $7.06 \%$ & 60.1 & 66.4 & 12,379 & 8,276 & 2,114 & 2,002 \\
\hline Average in 2011 & $16.50 \%$ & 83.6 & 77.8 & 12,716 & 8,213 & 2,878 & 3,229 \\
\hline
\end{tabular}

Source: Czech Business Register (Czech Ministry of Justice, 2013), own calculations.

The second indicator captures investment costs required per $\mathrm{MW}_{e}$, by taking fixed assets (called property, plant and equipment, or PPE) and dividing PPE by generating capacity. The PPE to capacity ratio is of crucial importance, as it will help us evaluate total investments in Czech PV plants. This ratio can also be seen as cost per unit $\mathrm{MW}_{e}$ of generating capacity. As can be seen from the data, average cost of $1 \mathrm{MW}_{e}$ for the 2010 sample amounts to CZK 68 million (approx. EUR 2.7 million). There are also significant differences across single plants. BS Park cost per $\mathrm{MW}_{e}$ is mere CZK 16 million, which can be explained by the fact that most of the production capacity was installed in 2010, while the financials are from 2009. Average cost of the remaining four plants is then CZK 81 million per $\mathrm{MW}_{e}$, which is very close to the average cost for the 2011 sample of CZK 84 million. Variation at the upper end can be explained by differences in location (cost of land) and in cost of technology.

Lastly we turn back to financing and evaluate the amount of liabilites (both current and long term) per $\mathrm{MW}_{e}$ of capacity. For the 2010 sample the liabilities to capacity ratio is CZK 69 million and for 2011 the ratio is 78 million. This simply means that most 
of the PPE investments are debt financed and it underlines once again the important role of creditors, especially banks, in the Czech PV sector, which will prove important in further discussion.

For 2010 we even see a situation where the liabilities per $\mathrm{MW}_{e}$ are higher than PPE per $\mathrm{MW}_{e}$. This implies that liabilities of the sample plants are so high that they finance not only all of the fixed assets but also part of the current (short-term) assets, which can be e.g. short-term accounts receivable.

\subsection{Income Statement Indicators}

For eight PV plants we were able to match production data with the respective income

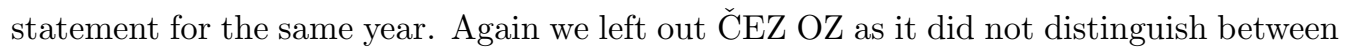
$\mathrm{PV}$ power and other renewable sources.

Table 2 shows selected figures from the income statement. If we measure the profitability by earnings before interest, taxes, depreciation and amortization (EBITDA), it can be seen that EBITDA margin (the ratio of EBITDA to revenue) is very high, averaging $89.4 \%$ for 2010 and $64.6 \%$ for 2011 . PV plants do not require any full-time employees. Maintenance and servicing costs are recorded as cost of services. EBITDA then covers two major cost items: depreciation and interest payments. After accounting for these, the listed plants were able to cash in profits before tax of CZK 3,717 per MWh in 2010, which is equivalent to almost EUR 150 per MWh. For the 2011 sample this profit before tax amounted to CZK 2,106. Note that in both cases the profit before tax itself is higher than average wholesale price of traded electricity, which was 1,087 CZK/MWh in 2010 and 1,098 CZK/MWh in 2011 (see section 3.4).

Table 3 relates income statement indicators to the respective balance sheet figures. EBITDA to assets ratio indicates how asset intensive the business is. The $12 \%$ for 2010 and $10 \%$ for 2011 will enter our evaluation of total cost of subsidies in the next section.

Depreciation is at the expected level of $5 \%$ for 2010, meaning that the plant will be completely written off after 20 years. The 2011 sample shows lower depreciation of $4 \%$ and longer depreciation period of 25 years, which points at an improvement in PV technology. Interest rate on debt stood at $6.4 \%$ for 2010 and $5.4 \%$ for 2011, reflecting the perceived predictability of returns at the time of construction.

\subsection{Market Value of PV Electricity}

To calculate PV costs, we needed to estimate the shadow market price of PV electricity. We started with wholesale market prices from OTE. OTE is a Czech state-owned company which organizes short-term wholesale market with electricity and natural gas 
Table 3: Profitability Ratios for Sample PV Plants.

\begin{tabular}{|c|c|c|c|}
\hline & $\frac{\text { EBITDA }}{\text { Assets }}$ & $\frac{\text { Depreciation }}{\text { PPE }}$ & $\frac{\text { Interest }}{\text { Debt }}$ \\
\hline \multicolumn{4}{|l|}{2010 sample } \\
\hline REN POWER II & $14.8 \%$ & $6.5 \%$ & $6.5 \%$ \\
\hline Solar Stribro & $7.7 \%$ & $3.8 \%$ & $6.3 \%$ \\
\hline FVE Czech & $12.8 \%$ & $3.8 \%$ & $6.5 \%$ \\
\hline Average in 2010 & $11.8 \%$ & $4.7 \%$ & $6.4 \%$ \\
\hline \multicolumn{4}{|l|}{2011 sample } \\
\hline 3L Invest & $8.4 \%$ & $2.1 \%$ & $3.1 \%$ \\
\hline FVE Czech Novum & $11.2 \%$ & $3.7 \%$ & $6.9 \%$ \\
\hline Gentley & $10.3 \%$ & $5.0 \%$ & $8.5 \%$ \\
\hline AREA-GROUP CL & $7.6 \%$ & $2.0 \%$ & $3.2 \%$ \\
\hline DOMICA FPI & $11.7 \%$ & $5.1 \%$ & $7.0 \%$ \\
\hline ŽV - SUN & $6.4 \%$ & $4.8 \%$ & $5.5 \%$ \\
\hline Divalia & $13.8 \%$ & $4.2 \%$ & $3.7 \%$ \\
\hline Average in 2011 & $9.9 \%$ & $3.9 \%$ & $5.4 \%$ \\
\hline
\end{tabular}

delivered at the Czech virtual trading point. Participants trade mostly with day-ahead or intra-day electricity, and moreover they are allowed to trade with their distribution network imbalances. Market data is publicly available at the website of OTE (OTE, 2013). These hourly wholesale prices can be viewed as marginal commodity electricity prices for the given hour of the year. The anual unweighted average wholesale market price from these data was 1,087 CZK/MWh in 2010 and 1,098 CZK/MWh in 2011.

However, to obtain the shadow PV price, we needed to weight these hourly wholesale prices by hourly electricity production of PV plants. Such data are not publicly available. ČEPS, the state-owned operator of the electricity distribution network, kindly provided us with unique data on hourly production of Czech PV plants in 2010 and 2011. To the best of our knowledge this is therefore the first attempt to calculate shadow PV price of Czech PV plants directly from PV plant production. As described in the report by California Solar Energy Industries Association (CALSEIA, 2010), this calculation reflects the value added of PV production in peak hours during the day when wholesale market price is higher. The fact that electricity produced in some hours of the day can have higher value due to higher demand in these peak hours is called the time-of-delivery factor.

To each hourly production of PV plants (from the 1st to the 8,760th hour in the year) we then assigned the corresponding wholesale market price from hourly trading data from OTE. PV plants only produce electricity when there is sunlight, and for majority of the 
hours we had available the corresponding hourly wholesale price from trading. There were some missing prices however, because for some hours there were no recorded trades at OTE exchange.

We wanted to assign a price to non-zero hourly production of PV plants even if no recorded trade was available in that hour. For each hour of the day (from 1 to 24) we calculated yearly average wholesale trading price in that hour. Thus we arrived at 24 annual average hourly prices $P^{1}$ to $P^{24}$ used to replace missing values:

$$
P^{t}=\frac{\sum_{d=1}^{365} P_{d}^{t}}{\sum_{d=1}^{365} \mathbb{I}\left(P_{d}^{t}>0\right)} \text { for } t=1, \ldots, 24,
$$

where $P_{d}^{t}$ is OTE wholesale market price for hour $t$ on day $d$ (if no recorded price exists then $\left.P_{d}^{t}=0\right)$ and $\mathbb{I}(\cdot)$ is the indicator function. If PV plants produced $17 \mathrm{MWh}$ of electricity in the 9th hour on January 1st 2010, but there was no recorded price at OTE exchange, we used the average price for the 9th hour of all days in 2010 where there were recorded trades $\left(=P^{9}\right)$.

In 2010 PV plants had non-zero production in 5,005 hours of the year, and for 1,379 hours $(27.6 \%)$ we had to use the hourly average price. The computation yields the shadow market price of PV electricity of 1,091.5 CZK per MWh (43.7 EUR/MWh). We see that the time-of-delivery factor of PV plants was positive but negligible $(0.4 \%)$.

In $2011 \mathrm{PV}$ plants had non-zero production in 5,730 hours of the year, and for 785 hours $(13.7 \%)$ we had to use the annual average hourly prices $\left(P_{1}\right.$ to $\left.P_{24}\right)$. The computation yields the shadow market price of PV electricity of $\mathbf{1 , 0 8 3 . 9}$ CZK per MWh (43.4 EUR/MWh). In 2011 the time-of-delivery factor of PV plants was negative (-1.3\%), meaning that PV plants produced in those hours when demand was lower compared to all-day average.

We will use this result in the section 4 to estimate PV costs in the Czech Republic.

\section{Cost of PV Subsidies}

\subsection{Income Method}

One method to calculate cost of PV subsidies is to evaluate the sum of feed-in tariffs above market price. This way we can get a simple approximation of how much money must be extracted from the rest of the economy and shifted to the PV business. Table 4 shows Czech feed-in tariffs as they were set by the Energy Regulatory Office for 2011. The decisive factor for receiving the subsidy is the year of installation (vintage). Every year the regulator updates the FIT for all past vintages (2006-2010) by a small inflation parameter and sets the subsidy for the new latest vintage (2011 in our case). We weighted 
average feed-in tariff (column 4 in table 4) by newly installed capacity in the given year (calculated from column 5).

Table 4: Feed-in Tariffs and Installed Capacity

\begin{tabular}{|c|c|c|c|c|c|c|}
\hline \multirow{2}{*}{$\begin{array}{c}C Z K / M W h \\
\text { Year of Construction }\end{array}$} & \multicolumn{3}{|c|}{ Plant Capacity } & \multirow{2}{*}{$\begin{array}{l}\text { Average } \\
\text { Cols. 1-3 }\end{array}$} & \multirow{2}{*}{$\begin{array}{r}\text { Installed Capacity } \\
M W, \text { year end }\end{array}$} & \multirow{2}{*}{$\begin{array}{l}\text { Weighted } \\
\text { avg. FIT }\end{array}$} \\
\hline & $<30 \mathrm{~kW}$ & $30-100 \mathrm{~kW}$ & $>100 \mathrm{~kW}$ & & & \\
\hline$<2006$ & \multicolumn{3}{|c|}{6,990} & 6,990 & 0 & 0 \\
\hline 2006,2007 & \multicolumn{3}{|c|}{14,660} & 14,660 & 3.6 & 14,660 \\
\hline 2008 & \multicolumn{3}{|c|}{14,300} & 14,300 & 39.5 & 14,333 \\
\hline 2009 & 13,420 & \multicolumn{2}{|c|}{13,320} & 13,370 & 464.4 & 13,452 \\
\hline 2010 & 12,500 & \multicolumn{2}{|c|}{12,400} & 12,450 & $1,820.0$ & 12,706 \\
\hline 2011 & 7,500 & 5,900 & 5,500 & 6,300 & $1,971.0$ & 12,215 \\
\hline
\end{tabular}

Note: Last column is cumulative average weighted by capacity additions in the given year.

Source: ERÚ (2010).

In table 5 we estimated the cost from the difference between average feed-in tariffs from table 4 and average market prices. We used two different average market prices: (1) The shadow PV price calculated in section 3.4 which is the average of those hours when PV plants actually produce electricity, and (2) average of all hourly settlement prices from the Czech short-term electricity market operated by OTE, weighted by volume of trading. If PV plants have a positive time-of-delivery factor, then the latter will overstate the costs of PV electricity, and vice versa. As discussed in section 3.4, the difference between both averages is rather small as the time-of-delivery factor is negligible. For 2009 we did not calculate the shadow price, so that we only used method (2).

The total cost of PV subsidies amounted to approximately CZK 7.2 billion (EUR 288 million), in 2010 and to CZK $\mathbf{2 4 . 3}$ billion (EUR 972 million) in 2011. As we discussed in section 2 , this is equal to both the DWL $\left(p_{02}\right)$ and the profit $\left(p_{03}\right)$ component of the subsidies. Because the market price and the shadow PV price do not differ significantly, the presented result is robust with respect to the base price used.

Because FIT tariffs are paid for on-site PV generation, all presented calculations are based on the comparison with the wholesale commodity price represented by the Prague Energy Exchange which equally applies to all on-site generation (PV as well as other sources). The electricity price paid by final consumers consists of additional components irrespective of the source, such as (1) transmission and distribution network fees, (2) transmission and distribution losses, (3) fees for the operation of the market maker OTE and (4) contribution to renewable subsidies (the renewable tax depicted in figure 1).

For illustration consider that in 2009 the average final electricity price was 4,128 
Table 5: Cost of PV Subsidies: Income Method

\begin{tabular}{c|rrrrr}
\hline Year & $\begin{array}{r}\text { Production } \\
M W h\end{array}$ & Feed-in tariff & $\begin{array}{r}\text { Wholesale market price } \\
\text { average, } C Z K / M W h\end{array}$ & $\begin{array}{c}\text { Shadow PV price } \\
\text { PV cost } \\
\text { avZK mil. }\end{array}$ \\
\hline $2009(2)$ & 88,800 & 13,452 & 1,026 & 1,103 \\
$2010(1)$ & 615,700 & 12,706 & & 1,092 & 7,151 \\
$2010(2)$ & 615,700 & 12,706 & 1,087 & & 7,154 \\
$2011(1)$ & $2,182,000$ & 12,215 & & 1,084 & 24,288 \\
$2011(2)$ & $2,182,000$ & 12,215 & 1,098 & & 24,257 \\
\hline
\end{tabular}

Source: ERÚ (2012), OTE (2013), own calculation.

CZK/MWh for households and 4,487 CZK/MWh for companies, including value added tax of $19 \%$ (Lukáš, 2011, part 6, p. 2). Table 5 shows that average feed-in tariff was about twelve times higher than the market price, and almost three times higher than final consumer price of electricity.

\subsection{Tied-up Resources}

The method which we described in the previous section does not completely account for resources which are tied up in PV plants over the period of their lifetime. Construction of solar plants requires significant investments in fixed assets, including land plots and PV panels. Solar panels are not versatile and cannot be employed elsewhere except for electricity generation. Ecological liquidation or recycling of materials used in the panels is questionable and costly.

As such fixed assets sunk in the PV sector represent resources which are missing in other sectors of the economy. Normally PPE costs (depreciation and foregone land rent) are covered by company earnings, however given that PV plants are loss making on a market basis, these resources could have been invested in a more efficient way, generating higher economic value added and increasing general wealth. To analyze the one-off loss to the economy represented by PV assets, we estimate the sum of PPE which are committed to PV plants for a period of their depreciation.

For the 2010 sample we calculated that each $\mathrm{MW}_{e}$ of generation capacity requires roughly CZK 68 million in PPE (table 2). Multiplying this by installed capacity of 1,820 $\mathrm{MW}_{e}$ as of 2010, this yielded total resources amounting to CZK 123.8 billion which were taken from other sectors. We showed in table 3 that average depreciation for the surveyed plants equals $5 \%$, which corresponds to 20 -year depreciation period. We can sum up that as a result of PV subsidies the economy has to withstand a shock of about CZK 6.2 billion (EUR 248 million) annually for 20 years - these are capital expenditures that 
have to be directed from other sectors to PV plant building. Since this calculation does not capture foregone land rent, it represents a low-end estimate of the costs of PV subsidies.

Running the same calculation for the 2011 sample, we arrived at CZK 165.6 billion of tied-up resources $(=0.084 \times 1,971)$. Depreciating this over 25 years $(4 \%$ depreciation rate) leads to an annual shock of CZK 6.6 billion (EUR 265 million). These numbers do not directly estimate losses, as there will be electricity production on one hand and further variable costs on the other hand. In addition, the tied-up resources would have partly been invested in other electricity generation capacity, so that the net shock to the remaining sectors excluding elecricity is lower. However it illustrates the magnitude of adjustments that are needed as a result of PV subsidies and that increase the volatility of doing business in the Czech Republic.

\subsection{Profit Accounting Method}

Finally, profits or losses stemming from PV subsidies can be estimated from microeconomic data based on average profit or loss margin of PV plants. We can formalize this idea as

$$
P L=\text { Profitability before tax } \times \text { PPE , }
$$

where $P L$ are costs of subsidies to the economy.

To derive the profitability we can start from standard profit accounting:

$$
\begin{aligned}
P L= & \text { Revenues }- \text { Costs } \\
= & \text { capacity } \times \text { usage } \times \text { electricity price }- \\
& - \text { depreciation }- \text { interest } \\
= & \frac{\mathrm{PPE}}{\text { cost per } \mathrm{MW}} \times \text { usage } \times \text { electricity price }- \\
& -\mathrm{PPE} \times \text { depreciation rate }- \\
& -\mathrm{PPE} \times \frac{\mathrm{debt}}{\mathrm{PPE}} \times \text { interest rate } .
\end{aligned}
$$

We used the fact that PPE is a multiple of capacity and unit cost of $\mathrm{MW}_{e}$. Denoting depreciation $\delta$, leverage $\lambda=\frac{\text { debt }}{\mathrm{PPE}}$ and interest rate $i$ we finally derive:

$$
\begin{aligned}
P L & = \\
\mathrm{PPE} & \times\left[\frac{\text { usage } \times \text { electricity price }}{\text { cost per MW }}-\delta-\lambda \times i\right]
\end{aligned}
$$


The following equation indicates units of each of the variables:

$$
\begin{aligned}
P L & = \\
{[\mathrm{CZK}] } & \times\left\{\frac{[\mathrm{h}] \times[\mathrm{CZK} / \mathrm{MWh}]}{[\mathrm{CZK} / \mathrm{MW}]}-[\%]-[\%] \times[\%]\right\} \\
& =[\mathrm{CZK}]
\end{aligned}
$$

We first calculated this value for the 2010 sample. As described in the previous section $\mathrm{PPE}=123.8$ billion CZK. We take average usage of the plants from table 1: usage $=734$ hours. Depreciation and interest rate are from table 3. We calculated leverage $\lambda$ as the ratio of liabilities to fixed assets to get $\lambda_{2010}=1.11$.

By plugging in the numbers we get

$$
\begin{aligned}
P L= & 123.8 \times \\
& {\left[\frac{734 \times 1,092}{68,000,000}-0.047-1.11 \times 0.064\right] } \\
= & 123.8 \times[0.012-0.047-0.071] \\
= & 123.8 \times(-0.11)
\end{aligned}
$$

These numbers indicate that investments into PV plants without government support would be making a guaranteed loss of $11 \%$ of the original committment every year. The whole investment would be written off after less than ten years and over the expected lifetime of 15 years the investors would have lost 1.5 times the upfront investment. The reason for the loss is obvious: Market price reflecting customer demand is not sufficient to cover high investment costs for PV technology. Note that high costs have to be understood as costs per usable hour, as PV plants have very low uptimes below $10 \%$ of the year.

Given the estimated value sunk in PV plants as of December 2010, annual economic loss generated by Czech photovoltaics stood at CZK 13.6 billion (EUR 545 million).

The same calculation for the 2011 sample with $\lambda_{2011}=0.95$ gives

$$
\begin{aligned}
P L= & 165.6 \times \\
& {\left[\frac{1,099 \times 1,084}{84,000,000}-0.039-0.95 \times 0.054\right] } \\
= & 165.6 \times[0.014-0.039-0.051] \\
= & 165.6 \times(-0.076)
\end{aligned}
$$


The loss ratio in 2011 was lower due to both lower depreciation rates and lower interest rates. It is more than compensated by longer depreciation period, i.e. a smaller loss is spread over more years.

Taking the assets invested in the Czech PV plants as of December 2011, annual economic loss of these plants amounted to CZK 12.6 billion (EUR 503 million).

From decomposition in equation (1) we can see that $\delta$ corresponds to the pure DWL component $p_{02}$ caused by the high cost of technology. Hence $\frac{\delta}{\delta+\lambda \times i}$ share of the loss belongs to $p_{02}$, which in our case is $40 \%$ in 2010 and $43 \%$ in 2011 (CZK 5.4 billion for both years). The remaining part constitutes the redistributive profit component $p_{03}$, amounting to CZK 8.2 billion in 2010 and 7.2 billion in 2011. The bulk of this money was cashed in by financing banks (in the form of interest payments) for whom the PV plants are steady sources of cash flow.

Finally, our calculation (3) has the advantage of enabling sensitivity analysis. Suppose that the uptime of the plants could be doubled due to higher insolation: The resulting loss on invested assets would still be $-6.2 \%$ for 2011 . The same holds for solar electricity price. Only when the price is increased about sevenfold do the plants turn profitable. Equivalently, the cost of PV technology would have to go down about sevenfold to guarantee profitability.

\section{Discussion}

Czech Republic has relatively large reserves of mineral resources for electricity generation, especially of lignite and hard coal (Kavina et al., 2009). As this paper shows, renewable energy sources can create significant cost effects compared to conventional sources, which leads to consequent price increases for consumers. Given that nominal Czech GDP in 2011 was roughly 3,823 billion, the PV shocks could at the upper end (CZK 24 billion) account for over $0.5 \%$ of GDP.

Studies such as Ratti et al. (2011) document that electricity price fluctuations can have major impact on the production side of the economy. In the example of Ratti et al. (2011) "a $1 \%$ rise in real energy prices reduces investment by a country's firm by $1.9 \%$ relative to that by firms in other countries." It is therefore crucial to understand the background of policies that led to PV subsidies.

We discussed in section 2.3 that Czech PV subsidies were adopted due to binding directives of the EU, more details on this procedure are contained e.g. in Sivek et al. (2012a). On the other hand, there is apparently some flexibility within this directive and within the procedure of setting the national target. For example, the new management 
of the Energy Regulatory Office promptly decided to halt PV subsidies for any new installations above $30 \mathrm{~kW}_{e}$ (ERÚ, 2012), while Sivek et al. (2012b) and others have called for deeper evaluation of renewable subsidies.

It is clear that PV subsidies set in the past will generate costs for many years in the future. The lesson is straightforward: If there is a policy which is bound to create a long-term impact, it appears wise to spend one additional year on proper analysis than to accept quick but potentially problematic solutions.

\section{Conclusions}

This paper derived the cost of PV plants from their microeconomic operating scheme. As a background we described the economics of PV subsidies and show how they create a redistributive distortion equivalent to a regressive tax. The core of the text is empirical: We provided a financial survey of a small sample of Czech PV plants. To evaluate the extent of market losses, we calculated the shadow market price of solar electricity. From the profit and loss accounts of the PV plants and the shadow market price we estimated the total economic loss generated by PV electricity sector.

The presented microeconomic approach has two main advantages: Firstly, we worked with real observed data, which in our view offsets the drawback of a limited sample. Secondly, the profit accounting calculation in section 4.3 enabled sensitivity analysis with respect to key variables of the plants.

As the main result of our model, we showed that every million invested in PV plants would generate an annual loss of 8\%. Given the estimated solar assets of CZK 165.6 billion (EUR 6.6 billion) as of December 2011, this translates in at least CZK 12.6 billion lost in the Czech solar sector in 2012. About $43 \%$ of this loss is due to high technology costs and corresponds to pure dead weight loss, while the remaining $57 \%$ constitute the redistributive profit component of subsidies which mostly flows to financing banks as guaranteed interest income. Finally, we calculated that unless electricity prices go up or technology costs go down about tenfold, PV plants will stay in red figures.

Besides this bottom-up model, we also estimated PV costs by means of two top-down calculations, which we called the income method and the tied-up resources method. These estimates put the annual shocks caused by PV plants in the range of CZK 6.224.3 billion.

In light of these costs the question naturally arises how can we justify the massive state support of PV plants. The usual answer is in order: Namely that state policies are much more often than they are not guided by motives other than economic logic. 


\section{Acknowledgements}

The research leading to these results has received funding from the People Programme (Marie Curie Actions) of the European Union's Seventh Framework Programme FP7/2007-2013/ under REA grant agreement number 609642. The authors further acknowledge financial support from the Czech Science Foundation (grants number P402/11/0948 and P402/12/0982) and from institutional support grant VSE IP100040. Karel Janda acknowledges research support provided during his long-term visits at Toulouse School of Economics, Australian National University and University of California, Berkeley.

\section{References}

Barbose, G., Darghouth, N., Wiser, R., 2012. Tracking the Sun V: An Historical Summary of the Installed Price of Photovoltaics in the United States from 1998 to 2011. Technical Report. Lawrence Berkeley National Laboratory.

Bloomberg, 2010. July 29, 2010. http://www.bloomberg.com/news/2010-07-29/spain-toinvestigate-solar-plant-irregularities-government-official-says.html.

Bloomberg, 2011a. August 15, 2011. http://www.bloomberg.com/news/2011-08-15/evergreen-solarseeks-bankruptcy-protection-with-debt-of-486-5-million.html.

Bloomberg, 2011b. December 14, 2011. http://www.bloomberg.com/news/2011-12-14/german-solarstock-pioneer-solon-plummets-on-insolvency-filing.html.

Bloomberg, 2011c. November 11, 2011. http://www.bloomberg.com/news/2011-11-10/solar-glut-toworsen-after-prices-plunge-93-on-rising-supply-commodities.html.

Bloomberg, 2011d. October 17, 2011. http://www.bloomberg.com/news/2011-10-17/solyndra-judgedenies-u-s-request-to-put-trustee-in-charge-of-bankruptcy.html.

Borenstein, S., 2007. Electricity Rate Structures and the Economics of Solar PV: Could Mandatory Time-of-Use Rates Undermine California's Solar Photovoltaic Subsidies? Working Paper 172. Center for the Study of Energy Markets.

Borenstein, S., 2008. The Market Value and Cost of Solar Photovoltaic Electricity Production. Working Paper 176. Center for the Study of Energy Markets.

CALSEIA, 2010. Small-scale solar photovoltaics in California: Incremental value not captured in the 2009 market price referent — Description of methodology. Technical Report. California Solar Energy Industries Association.

Czech Ministry of Industry, 2010. National Renewable Energy Action Plan. http://www.mpo.cz/ dokument79564.html.

Czech Ministry of Justice, 2013. Czech Business Register. http://www.justice.cz/.

Dusonchet, L., Telaretti, E., 2010a. Economic analysis of different supporting policies for the production of electrical energy by solar photovoltaics in eastern European Union countries. Energy Policy 38, 4011-4020.

Dusonchet, L., Telaretti, E., 2010b. Economic analysis of different supporting policies for the production of electrical energy by solar photovoltaics in western European Union countries. Energy Policy 38, 3297-3308. URL: http://www.sciencedirect.com/science/article/pii/S0301421510000819, doi:10.1016/j.enpol.2010.01.053. 
ERÚ, 2009. Price decree 7/2009. Energetický Regulační Úřad.

ERÚ, 2010. Price decree 2/2010. Energetický Regulační Úřad.

ERÚ, 2011. Price decree 5/2011. Energetický Regulační Úřad.

ERÚ, 2012. Price decree 8/2012. Energetický Regulační Úřad.

ERÚ, 2012. Roční zpráva o provozu ES ČR 2011. Technical Report. Energetický regulační úřad.

European Council, 2009. Directive 2009/28/EC of the European Parliament and of the Council of 23 april 2009 on the promotion of the use of energy from renewable sources.

Gowrisankaran, G., Reynolds, S.S., Samano, M., 2011. Intermittency and the Value of Renewable Energy. Working Paper 17086. National Bureau of Economic Research. URL: http://www.nber.org/papers/ w17086.

Kavina, P., Jirásek, J., Sivek, M., 2009. Some issues related to the energy sources in the Czech Republic. Energy Policy 37, 2139-2142.

Lewandowski, I., Weger, J., van Hooijdonk, A., Havlickova, K., van Dam, J., Faaij, A., 2006. The potential biomass for energy production in the Czech Republic. Biomass and Bioenergy 30, 405-421.

Lukáš, J., 2011. Roční zpráva o provozu ES ČR 2010. Technical Report. Energetický regulační úr̆ad.

OTE, 2013. Operátor trhu s elektřinou. http://www.ote-cr.cz/.

Pearce, J.M., 2002. Photovoltaics — a path to sustainable futures. Futures 34, 663-674. URL: http://www.sciencedirect.com/science/article/pii/S0016328702000083, doi:http://dx. doi.org/10.1016/S0016-3287(02)00008-3.

Ratti, R.A., Seol, Y., Yoon, K.H., 2011. Relative energy price and investment by European firms. Energy Economics 33, 721-731. doi:10.1016/j.eneco.2010.12.010.

Sandén, B.A., 2005. The economic and institutional rationale of PV subsidies. Solar Energy 78, 137146. URL: http://www.sciencedirect.com/science/article/pii/S0038092X04000726, doi:http:// dx.doi.org/10.1016/j.solener.2004.03.019.

Sivek, M., Kavina, P., Malečková, V., Jirásek, J., 2012a. Czech Republic and indicative targets of the European Union for electricity generation from renewable sources. Energy Policy 44, 469475. URL: http://www.sciencedirect.com/science/article/pii/S0301421512000808, doi:http: //dx.doi.org/10.1016/j.enpol.2012.01.054.

Sivek, M., Kavina, P., Malečková, V., Jirásek, J., 2012b. Factors influencing the selection of the past and future strategies for electricity generation in the Czech Republic. Energy Policy 48, 650656. URL: http://www.sciencedirect.com/science/article/pii/S0301421512004867, doi:http: //dx.doi.org/10.1016/j.enpol.2012.05.073.

Smrčka, L., 2011. Photovoltaics in the Czech Republic — Example of a Distorted Market, in: 6th IASME/WSEAS International Conference on Energy and Environment, pp. 378-383.

The Boston Consulting Group, 2011. BCG Perspective on PV Market.

Timilsina, G.R., Kurdgelashvili, L., Narbel, P.A., 2011. A Review of Solar Energy: Markets, Economics and Policies. Working Paper 5845. The World Bank. URL: http://www.nber.org/papers/w17086.

Š́ri, M., Huld, T.A., Dunlop, E.D., Ossenbrink, H.A., 2007. Potential of solar electricity generation in the European Union member states and candidate countries. Solar Energy 81, 12951305. URL: http://www.sciencedirect.com/science/article/pii/S0038092X07000229, doi:10. 1016/j.solener.2006.12.007.

Wiser, R., Barbose, G., Peterman, C., Darghouth, N., 2009. Tracking the Sun II: The Installed Cost of Photovoltaics in the U.S. from 1998-2008. Technical Report. Lawrence Berkeley National Laboratory. 